\title{
Communication \\ Halogen Bonding in Isostructural Co(II) Complexes with 2-Halopyridines
}

\author{
Sergey A. Adonin ${ }^{1,2, *}$, Mikhail A. Bondarenko ${ }^{1}$, Alexander S. Novikov ${ }^{3}$ and Maxim N. Sokolov ${ }^{1}$ \\ 1 Nikolaev Institute of Inorganic Chemistry SB RAS, Lavrentieva St., 630090 Novosibirsk, Russia; \\ langus8431@gmail.com (M.A.B.); caesar@niic.nsc.ru (M.N.S.) \\ 2 South Ural State University, Lenina St. 76, 454080 Chelyabinsk, Russia \\ 3 Saint Petersburg State University, Institute of Chemistry, Universitetskaya Nab. 7-9, \\ 199034 Saint Petersburg, Russia; ja2-88@mail.ru \\ * Correspondence: adonin@niic.nsc.ru
}

Received: 27 March 2020; Accepted: 8 April 2020; Published: 10 April 2020

\begin{abstract}
Three complexes $\left[\mathrm{Co}(2-\mathrm{XPy})_{2} \mathrm{Cl}_{2}\right](\mathrm{X}=\mathrm{Cl}, \mathrm{Br}$, and I) were prepared and characterized, representing a rare case of isostructurality within the $\mathrm{Cl}$-Br-I row. The nature of halogen bonding (XB) in a solid state was studied by DFT calculations, revealing a tendency of XB energy growth for heavier halogens.
\end{abstract}

Keywords: halogen bonding; cobalt; pyridines; DFT calculations

\section{Introduction}

Regarding all of the approaches in the field of crystal engineering, halogen bonding (XB) has attracted great interest within modern research [1,2]. This type of non-covalent interaction involving halogen atoms (according to the IUPAC-approved definition, the bond "occurs when there is evidence of a net attractive interaction between an electrophilic region associated with a halogen atom in a molecular entity and a nucleophilic region in another, or the same, molecular entity") becomes especially prominent in a solid state, and its appearance can affect numerous physical properties of matter, such as luminescence [3-5], solubility [6], color [7], and so forth, therefore providing an additional tool for material design [8-10].

From the point of view of physical chemistry, the key parameter of XB is its energy, which mainly depends on the environment of the halogen atoms participating in the formation of non-covalent contacts. However, the effects of crystal packing can play a significant role as well [11]. Therefore, for the experimental estimation of the $\sigma$-hole-donating ability in certain building blocks (this feature is essential for $\mathrm{XB}$ formation [2]) of special interest are the cases where series of compounds containing different halogen atoms $(\mathrm{Cl}, \mathrm{Br}$, and I) are isostructural. This situation allows a direct comparison of energies in different $\mathrm{X} \cdots X$ pairs by means of theoretical methods. However, while $\mathrm{Cl} / \mathrm{Br}$ or $\mathrm{Br} / \mathrm{I}$ isostructural pairs are common, the 'triple' series are very rare $[12,13]$ especially in coordination chemistry [14,15].

Neutral complexes of general formula, $\left[\mathrm{M}(\mathrm{XPy})_{2} \mathrm{Y}_{2}\right](\mathrm{XPy}=$ halogen-substituted pyridine, $\mathrm{Y}=\mathrm{Cl}$, $\mathrm{Br}$ or I, $\mathrm{M}=$ divalent metal cations, i.a. $\mathrm{Cu}, \mathrm{Zn}, \mathrm{Co}, \mathrm{Cd}$, etc.) [16-23], represent a large family of coordination compounds which reveal a clear trend to form XB in a solid state. Surprisingly, the analysis of previously published XRD data indicates that complexes with 2-halopyridines (2-XPy) are less studied than those with 3-, 4- or polysubstituted pyridines. In relation to 2-XPy, there are structurally characterized examples for $\mathrm{Pd}$ [24], Co [25], and $\mathrm{Cu}$ [26-29], (1, 1, and 7, respectively), although the preparation procedures [30,31], the features of thermal decomposition [32], and IR spectra [33] for several relevant Co complexes were described earlier. In order to fill this gap, we prepared a series of 
cobalt(II) complexes of the general formula [Co(2-XPy)Cl 2$](\mathrm{X}=\mathrm{Cl}(\mathbf{1}), \mathrm{Br}(\mathbf{2})$ and I (3)) which, according to the XRD data, are isostructural (the maximal deviations of the unit cell parameters are $0.342 \AA$ ) and, therefore, represent an attractive and rare object for the study of $\mathrm{XB}$ nature.

\section{Materials and Methods}

All experiments were conducted in air. All reagents used were from commercial sources (Sigma-Aldrich) and used as purchased.

\subsection{Preparation of $\mathbf{1}-\mathbf{3}$}

The measurement of $100 \mathrm{mg}(0.42 \mathrm{mmol})$ of $\mathrm{CoCl}_{2} \cdot 6 \mathrm{H}_{2} \mathrm{O}$ was dissolved in $5 \mathrm{~mL}$ of ethanol, followed by the addition of 2-chloro $(84 \mu \mathrm{L}), 2$-bromo $(85 \mu \mathrm{L})$, or 2-iodopyridine $(90 \mu \mathrm{L})$, for $\mathbf{1}, \mathbf{2}$, or $\mathbf{3}$, respectively. The slow evaporation of the solvents (to $\approx 10 \%$ of the initial volume) resulted in the formation of blue crystals suitable for X-ray diffractometry. Yield: $86 \%$ (1), 88\% (2), 85\% (3); element analysis data are given in Table S1 (Supplementary Materials).

\subsection{X-ray Diffractometry}

Data for single crystals of 1-3 were obtained at $130 \mathrm{~K}$ on the Agilent Xcalibur diffractometer (version/model, Oxford Diffraction, UK) equipped with an area AtlasS2 detector (graphite monochromator, $\lambda(\mathrm{MoK} \alpha)=0.71073 \AA, \omega$-scans). The integration, absorption correction, and determination of unit cell parameters were performed using the CrysAlisPro program package (CrysAlisPro 1.171.38.41. Rigaku Oxford Diffraction: The Woodlands, TX, USA, 2015). The structures were solved using the dual space algorithm (SHELXT) and refined by the full-matrix least-squares technique (SHELXL) [34] in anisotropic approximation (except hydrogen atoms). The position of the hydrogen atoms of organic ligands was calculated geometrically and refined in the riding model. The crystallographic data and details of the structure refinements are summarized in Table S1 (Supplementary Materials). CCDC 1985498-1985500 contains the supplementary crystallographic data for this paper. The data can be obtained free of charge from The Cambridge Crystallographic Data Center at http://www.ccdc.cam.ac.uk/data_request/cif.

\section{Results and Discussion}

The formulas 1-3 are neutral. The coordination environment of the tetrahedral Co(II) consisted of two chloride and two pyridine ligands (Figure 1). The $\mathrm{Co}-\mathrm{Cl}$ and $\mathrm{Co}-\mathrm{N}$ bond lengths were very similar $(\mathrm{Co}-\mathrm{Cl}=2.236-2.250,2.238-2.253$, and 2.246-2.257 $\AA, \mathrm{Co}-\mathrm{N}=2.051-2.066,2.050-2.064$, and 2.057 $2.069 \AA$, respectively). The comparison of X...Cl distances (3.505-3.543, 3.401-3.418, and 3.393-3.400 in 1, 2, and 3) combined with the sum of the corresponding Bondi's van der Waals radii $(3.50,3.58$, and $3.73 \AA$ for $\mathrm{X}=\mathrm{Cl}, \mathrm{Br}$, and I $[35,36])$ indicates that corresponding non-covalent interactions must be present in $\mathbf{2}$ and $\mathbf{3}$ and, most likely, absent in $\mathbf{1}$. However, since it was known that "abnormally long" $\mathrm{XB}$ can exists, we decided to include 1 into the DFT analysis dataset.

For the estimation of XB energies in 1-3, we applied an approach that was successfully used by us earlier [37-40]: atomic coordinates were extracted from XRD data and used (without optimization, see Supplementary Materials) for DFT calculations (M06/DZP-DKH) and the topological analysis of the electron density distribution [41]. Results are presented in Table 1 and in Figure 2. 


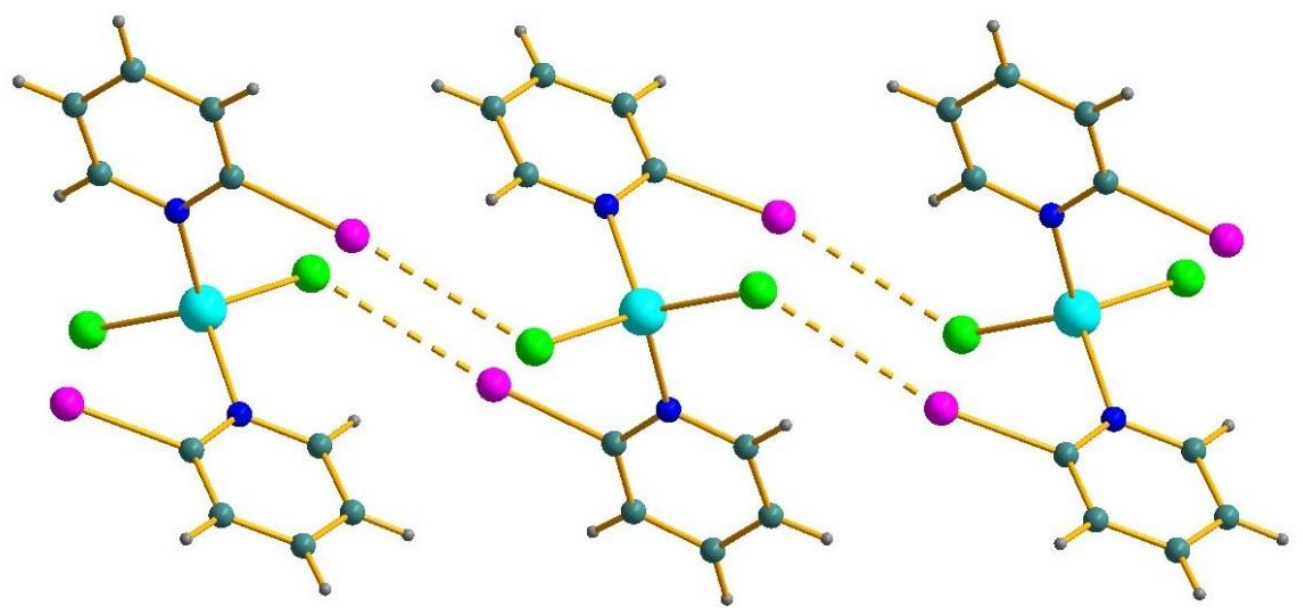

Figure 1. Halogen bonding (dashed) in the structure of 3. I purple, $\mathrm{Cl}$ green, $\mathrm{N}$ blue, Co cyan, $\mathrm{C}$ turquoise, $\mathrm{H}$ grey.

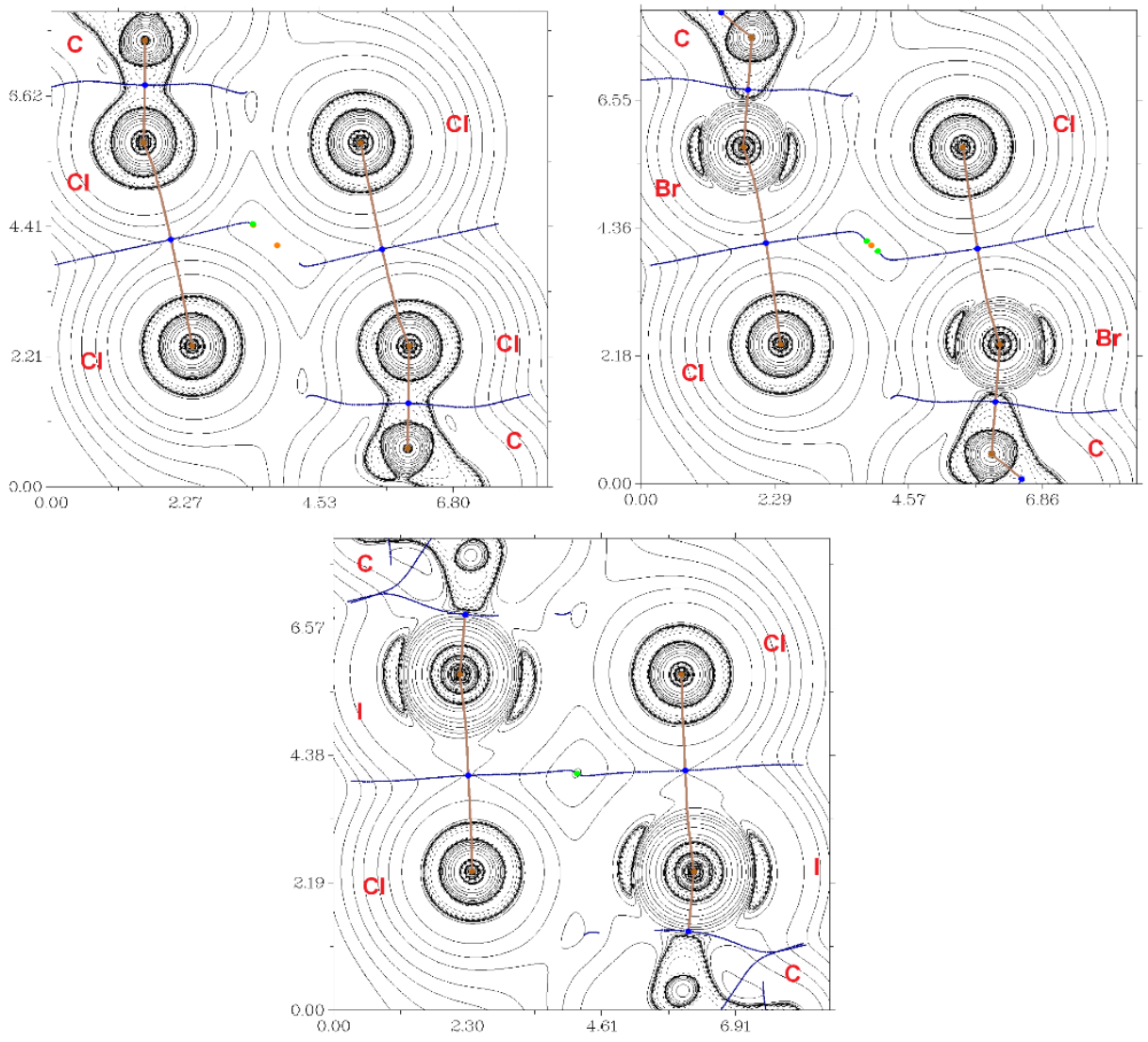

Figure 2. The contour lines demonstrate the Laplacian electron density distribution $\nabla^{2} \rho(\mathbf{r})$, bond paths, and selected zero-flux surfaces referring to the intermolecular non-covalent interactions of $X \cdots \mathrm{Cl}(X=\mathrm{Cl}$, $\mathrm{Br}, \mathrm{I})$ in $\mathbf{1}$ (top, left), $\mathbf{2}$ (top, right) and $\mathbf{3}$ (bottom). The critical bonding points $(3,-1)$ are shown in blue, the nuclear critical points $(3,-3)$ - in pale brown, ring critical points $(3,+1)$ - in orange, and length units - $\AA$.

According to the criterion proposed by Espinosa et al., the balance between the Lagrangian kinetic energy $G(\mathbf{r})$ and potential energy density $V(\mathbf{r})$ at the BCPs $(3,-1)$ indicates the nature of these interactions; if the ratio $-\mathrm{G}(\mathbf{r}) / \mathrm{V}(\mathbf{r})>1$, then the nature of the appropriate interaction is purely non-covalent; in the case of $-\mathrm{G}(\mathbf{r}) / \mathrm{V}(\mathbf{r})<1$, some covalent component occurs [42]; therefore, all considered interactions are purely non-covalent. For the estimation of XB energies, four diverse approaches were used [43-45]. 
The absolute values of $E_{\text {int }}$ calculated via these methods vary, but in all cases there was a clear trend: the energy increased in the $\mathrm{Cl}-\mathrm{Br}-\mathrm{I}$ row (the difference became especially prominent in the case of the approach proposed by Bartashevich et al. [45]). Interestingly, these correlated with the contributions of corresponding interactions to the molecular Hirshfeld surfaces (see Supplementary Materials, Table S2) which increased in the 1-2-3 sequence. All these facts confirmed that 2-iodopyridine was the best XB donor in 2-XPy series.

Table 1. Values of the density of all electrons $-\rho(\mathbf{r})$, Laplacian of electron density $-\nabla^{2} \rho(\mathbf{r})$ and appropriate $\lambda_{2}$ eigenvalues (with promolecular approximation), energy density $-\mathrm{H}_{\mathrm{b}}$, potential energy density $-V(\mathbf{r})$, and Lagrangian kinetic energy $-G(\mathbf{r})$ (a.u.) at the bonding of critical points $(3,-1)$, corresponding to intermolecular non-covalent interactions $\mathrm{X} \cdots \mathrm{Cl}(\mathrm{X}=\mathrm{Cl}, \mathrm{Br}, \mathrm{I})$ in $\mathbf{1}, \mathbf{2}$, and 3, as well as energies for these contacts $\mathrm{E}_{\text {int }}(\mathrm{kcal} / \mathrm{mol})$, defined by different approaches.

\begin{tabular}{|c|c|c|c|c|c|c|c|c|c|c|}
\hline Contact & $\rho(\mathbf{r})$ & $\nabla^{2} \rho(\mathrm{r})$ & $\lambda_{2}$ & $\mathbf{H}_{\mathrm{b}}$ & $V(r)$ & $G(r)$ & $E_{\text {int }}{ }^{a}$ & $E_{\text {int }} b$ & $E_{i n t}{ }^{c}$ & $E_{\text {int }}{ }^{d}$ \\
\hline \multicolumn{11}{|c|}{1} \\
\hline $\mathrm{Cl} \cdots \mathrm{Cl}, 3.505 \AA$ & 0.007 & 0.023 & -0.009 & 0.001 & -0.003 & 0.005 & 0.9 & 1.3 & 0.9 & 1.5 \\
\hline $\mathrm{Cl} \cdots \mathrm{Cl}, 3.543 \AA$ & 0.006 & 0.021 & -0.008 & 0.001 & -0.003 & 0.004 & 0.9 & 1.1 & 0.9 & 1.2 \\
\hline \multicolumn{11}{|c|}{2} \\
\hline $\mathrm{Br} \cdots \mathrm{Cl}, 3.401 \AA$ & 0.009 & 0.030 & -0.012 & 0.001 & -0.005 & 0.006 & 1.6 & 1.6 & 1.8 & 2.1 \\
\hline $\mathrm{Br} \cdots \mathrm{Cl}, 3.418 \AA$ & 0.009 & 0.029 & -0.012 & 0.001 & -0.005 & 0.006 & 1.6 & 1.6 & 1.8 & 2.1 \\
\hline \multicolumn{11}{|c|}{3} \\
\hline $\mathrm{I} \cdots \mathrm{Cl}, 3.393 \AA$ & 0.012 & 0.041 & -0.016 & 0.001 & -0.008 & 0.009 & 2.5 & 2.4 & 3.4 & 3.8 \\
\hline $\mathrm{I} \cdots \mathrm{Cl}, 3.400 \AA$ & 0.012 & 0.040 & -0.015 & 0.001 & -0.008 & 0.009 & 2.5 & 2.4 & 3.4 & 3.8 \\
\hline
\end{tabular}

a $\overline{E_{\text {int }}=-V(r) / 2 \text { for all types of non-covalent interactions [43]. }{ }^{b} E_{\text {int }}=0.429 G(r) \text { for all types of non-covalent }}$ interactions (this correlation was initially developed for hydrogen bonding) [44]. ${ }^{c} \mathrm{E}_{\text {int }}=0.49(-\mathrm{V}(\mathrm{r}))$, or $0.58(-\mathrm{V}(\mathrm{r})$ ), or $0.68(-\mathrm{V}(\mathrm{r}))$ for non-covalent interactions involving chlorine, bromine, and iodine atoms, respectively [45]. ${ }^{\mathrm{d}} \mathrm{E}_{\text {int }}=0.47 \mathrm{G}(\mathrm{r})$, or $0.57 \mathrm{G}(\mathrm{r})$, or $0.67 \mathrm{G}(\mathrm{r})$ for non-covalent interactions involving chlorine, bromine, and iodine atoms, respectively [45].

\section{Conclusions}

In this study, the isostructural complexes $\left[\mathrm{Co}(2-\mathrm{XPy}) \mathrm{Cl}_{2}\right]$ represent a rare case from the point of view of crystal engineering, making direct comparisons of XB donor properties of 2-XPy (those are most prominent for 2-iodopyridine). In our opinion, these facts confirmed that halogen-substituted $\mathrm{N}$-donor ligands are promising building blocks for the design of XB-based supramolecular systems (similar ideas were expressed earlier for 3- and 4-halogenated pyridines $[16,19,22,26,27,46])$, and this feature can be utilized in material science.

Supplementary Materials: The following are available online at http://www.mdpi.com/2073-4352/10/4/289/ s1. Table S1: Crystal data and structure refinement for 1-3, Table S2: Results of Hirshfeld surface analysis, computational details, Table S3: Cartesian atomic coordinates for model supramolecular associates 1, 2 and 3, Table S4: Element analysis data for 1-3.

Author Contributions: Conceptualization, S.A.A. and M.N.S.; methodology, S.A.A.; validation, M.A.B. and A.S.N.; formal analysis, A.S.N. and S.A.A.; investigation, A.S.N., M.A.B. and S.A.A.; resources, S.A.A.; data curation, S.A.A. and M.N.S, writing-original draft preparation, S.A.A.; project administration, S.A.A.; funding acquisition, S.A.A. All authors have read and agreed to the published version of the manuscript.

Funding: This research was funded by the Russian Foundation for Basic Research, grant number 20-33-70010.

Conflicts of Interest: The authors declare no conflict of interest.

\section{References}

1. Desiraju, G.R.; Ho, P.S.; Kloo, L.; Legon, A.C.; Marquardt, R.; Metrangolo, P.; Politzer, P.; Resnati, G.; Rissanen, K. Definition of the halogen bond (IUPAC Recommendations 2013). Pure Appl. Chem. 2013, 85, 1711-1713. [CrossRef]

2. Cavallo, G.; Metrangolo, P.; Milani, R.; Pilati, T.; Priimagi, A.; Resnati, G.; Terraneo, G. The Halogen Bond. Chem. Rev. 2016, 116, 2478-2601. [CrossRef] 
3. Sivchik, V.V.; Solomatina, A.I.; Chen, Y.-T.; Karttunen, A.J.; Tunik, S.P.; Chou, P.-T.; Koshevoy, I.O. Halogen bonding to amplify luminescence: A case study using a platinum cyclometalated complex. Angew. Chem. Int. Ed. 2015, 54, 14057-14060. [CrossRef] [PubMed]

4. Chowdhury, B.; Sinha, S.; Ghosh, P. Selective sensing of phosphates by a new bis-heteroleptic Ru ${ }^{\mathrm{II}} \mathrm{Complex}$ through halogen bonding: A superior sensor over its hydrogen-bonding analogue. Chem. A Eur. J. 2016, 22, 18051-18059. [CrossRef]

5. Xiao, L.; Wu, Y.; Yu, Z.; Xu, Z.; Li, J.; Liu, Y.; Yao, J.; Fu, H. Room-temperature phosphorescence in pure organic materials: Halogen bonding switching effects. Chem. A Eur. J. 2018, 24, 1801-1805. [CrossRef]

6. Kinzhalov, M.A.; Kashina, M.V.; Mikherdov, A.S.; Mozheeva, E.A.; Novikov, A.S.; Smirnov, A.S.; Ivanov, D.M.; Kryukova, M.A.; Ivanov, A.Y.; Smirnov, S.N.; et al. Dramatically enhanced solubility of halide-containing organometallic species in diiodomethane: The role of solvent..complex halogen bonding. Angew. Chem. Int. Ed. 2018, 57, 12785-12789. [CrossRef]

7. Adonin, S.A.; Gorokh, I.D.; Novikov, A.S.; Samsonenko, D.G.; Yushina, I.V.; Sokolov, M.N.; Fedin, V.P. Halobismuthates with halopyridinium cations: Appearance or non-appearance of unusual colouring. CrystEngComm 2018, 20, 7766-7772. [CrossRef]

8. Priimagi, A.; Cavallo, G.; Metrangolo, P.; Resnati, G. The halogen bond in the design of functional supramolecular Materials: Recent advances. Acc. Chem. Res. 2013, 46, 2686-2695. [CrossRef]

9. Buntara Sanjeeva, K.; Pigliacelli, C.; Gazzera, L.; Dichiarante, V.; Baldelli Bombelli, F.; Metrangolo, P. Halogen bond-assisted self-assembly of gold nanoparticles in solution and on a planar surface. Nanoscale 2019, 11, 18407-18415. [CrossRef]

10. Saccone, M.; Catalano, L. Halogen bonding beyond crystals in materials science. J. Phys. Chem. B 2019, 123, 9281-9290. [CrossRef]

11. Lin, J.; Chen, Y.; Zhao, D.; Lu, X.; Lin, Y. Versatile supramolecular binding modes of 1,4-diiodotetrafluorobenzene for molecular cocrystal engineering. J. Mol. Struct. 2019, 1187, 132-137. [CrossRef]

12. Saraswatula, V.G.; Saha, B.K. The effect of temperature on interhalogen interactions in a series of isostructural organic systems. New J. Chem. 2014, 38, 897-901. [CrossRef]

13. Saraswatula, V.G.; Saha, B.K. A thermal expansion investigation of the melting point anomaly in trihalomesitylenes. Chem. Commun. 2015, 51, 9829-9832. [CrossRef]

14. Buldakov, A.V.; Kinzhalov, M.A.; Kryukova, M.A.; Ivanov, D.M.; Novikov, A.S.; Smirnov, A.S.; Starova, G.L.; Bokach, N.A.; Kukushkin, V.Y. Isomorphous series of PdII-containing halogen bond donors exhibiting Cl/Br/I triple halogen isostructural exchange. Cryst. Growth Des. 2020. [CrossRef]

15. Chupina, A.V.; Shayapov, V.; Novikov, A.S.; Volchek, V.V.; Benassi, E.; Abramov, P.A.; Sokolov, M.N. $\left[\{\mathrm{AgL}\}_{2} \mathrm{Mo}_{8} \mathrm{O}_{26}\right]^{\mathrm{n}-}$ complexes: A combined experimental and theoretical study. Dalt. Trans. 2020, 49, 1522-1530. [CrossRef]

16. Awwadi, F.F.; Taher, D.; Maabreh, A.; Alwedian, F.Z.; Al-Ebaisat, H.; Rüffer, T.; Lang, H. The role of $\mathrm{Fe}-\mathrm{X} \cdots \mathrm{X}-\mathrm{Fe}$ contacts in the crystal structures of $\left[(2 \text {-iodopyridinium })_{2} \mathrm{FeX}_{4}\right] \mathrm{X}(\mathrm{X}=\mathrm{Cl}, \mathrm{Br})$. Struct. Chem. 2013, 24, 401-408. [CrossRef]

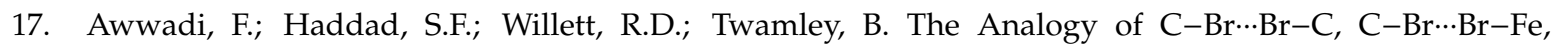
and $\mathrm{Fe}-\mathrm{Br} \cdots \mathrm{Br}-\mathrm{Fe}$ Contacts: Crystal Structures of $(26 \mathrm{DAPH}) \mathrm{FeBr}_{4}$ and $(26 \mathrm{DA} 35 \mathrm{DBPH})_{2} \mathrm{FeBr}_{4} \cdot \mathrm{Br}$. Cryst. Growth Des. 2010, 10, 158-164. [CrossRef]

18. Awwadi, F.F.; Taher, D.; Haddad, S.F.; Turnbull, M.M. Competition between hydrogen and halogen bonding interactions: Theoretical and crystallographic studies. Cryst. Growth Des. 2014, 14, 1961-1971. [CrossRef]

19. Puttreddy, R.; von Essen, C.; Rissanen, K. Halogen bonds in square planar 2,5-dihalopyridine-copper(II) bromide complexes. Eur. J. Inorg. Chem. 2018, 2018, 2393-2398. [CrossRef]

20. Farris, P.C.; Wall, A.D.; Chellali, J.E.; Chittim, C.L.; Landee, C.P.; Turnbull, M.M.; Wikaira, J.L. Copper(II) halide complexes of aminopyridines: Syntheses, structures and magnetic properties of $\left[(5 \mathrm{CAP})_{2} \mathrm{CuX}{ }_{2}\right]$ and [(5BAP $)_{\mathrm{n}} \mathrm{CuX}_{2}$ ] $(\mathrm{X}=\mathrm{Cl}, \mathrm{Br})$. J. Coord. Chem. 2018, 71, 2487-2509. [CrossRef]

21. Abdalrahman, M.; Landee, C.P.; Telfer, S.G.; Turnbull, M.M.; Wikaira, J.L. Copper(II) halide coordination complexes and salts of 3-halo-2-methylpyridines: Synthesis, structure and magnetism. Inorg. Chim. Acta 2012, 389, 66-76. [CrossRef]

22. Hu, C.; Li, Q.; Englert, U. Structural trends in one and two dimensional coordination polymers of cadmium(ii) with halide bridges and pyridine-type ligands. CrystEngComm 2003, 5, 519. [CrossRef] 
23. Wang, R.; Dols, T.S.; Lehmann, C.W.; Englert, U. The halogen bond made visible: Experimental charge density of a very short intermolecular $\mathrm{Cl} \cdots \mathrm{Cl}$ donor-acceptor contact. Chem. Commun. 2012, 48, 6830. [CrossRef] [PubMed]

24. Krogul, A.; Cedrowski, J.; Wiktorska, K.; Ozimiński, W.P.; Skupińska, J.; Litwinienko, G. Crystal structure, electronic properties and cytotoxic activity of palladium chloride complexes with monosubstituted pyridines. Dalton Trans. 2012, 41, 658-666. [CrossRef] [PubMed]

25. Hiltunen, L.; Niinistö, L.; Kenessey, G.; Keserü, G.M.; Liptay, G.; Kondow, A.J.; Bisht, K.S.; Parmar, V.S.; Francis, G.W. Pyridine-Type Complexes of Transition-Metal Halides. V. Preparation, Thermal Properties, Infrared Spectra and Crystal Structure of Dibromo-bis(2-bromopyridine)cobalt(II). Acta Chem. Scand. 1994, 48, 456-460. [CrossRef]

26. Awwadi, F.F.; Willett, R.D.; Twamley, B.; Turnbull, M.M.; Landee, C.P. Dual behavior of bromine atoms in supramolecular chemistry: The crystal structure and magnetic properties of two copper(II) coordination polymers. Cryst. Growth Des. 2015, 15, 3746-3754. [CrossRef]

27. Awwadi, F.; Willett, R.D.; Twamley, B. Tuning Molecular Structures Using Weak Noncovalent Interactions: Theoretical Study and Structure of trans -Bis(2-chloropyridine)dihalocopper(II) and trans -Bis(3-chloropyridine)dibromocopper(II). Cryst. Growth Des. 2011, 11, 5316-5323. [CrossRef]

28. Healy, P.C.; Kildea, J.D.; Skelton, B.W.; Waters, A.F.; White, A.H. Lewis-base adducts of group 11 metal(I) compounds. 60. Binuclear adducts of copper(I) halides with 2-hindered pyridine bases. Acta Crystallogr. Sect. C 1991, 47, 1721-1723. [CrossRef]

29. Awwadi, F.F.; Willett, R.D.; Haddad, S.F.; Twamley, B. The electrostatic nature of aryl-bromine-halide synthons: The role of aryl-bromine-halide synthons in the crystal structures of the trans-bis(2-bromopyridine) dihalocopper(II) and trans-bis(3-bromopyridine) dihalocopper(II) complexes. Cryst. Growth Des. 2006, 6, 1833-1838. [CrossRef]

30. Kenessey, G.; Werner, P.-E.; Wadsten, T.; Bidló, G.; Liptay, G. Pyridine-type complexes of transition-metal Halides VII. Thermal and structural properties of Cobalt(II) Halide complexes formed with 2-Halogenopyridines. Acta Chem. Scand. 1999, 53, 163-167. [CrossRef]

31. Billing, D.E.; Underhill, A.E. Complexes of cobalt(II) and nickel(II) halides with some halogenopyridines. J. Chem. Soc. A Inorg. Phys. Theor. 1968, 29-33. [CrossRef]

32. Mortimer, C.T.; McNaughton, J.L. The thermal decomposition of transition-metal complexes containing heterocyclic ligands. 3. Substituted pyridine complexes of cobalt. Thermochim. Acta 1974, 10, 125-128. [CrossRef]

33. McWhinnie, W.R. The far infra-red spectra of metal complexes containing substituted pyridines as ligands-II Complexes of cobalt (II) and copper (II) with 2-chloro- and 2-bromo-pyridine. J. Inorg. Nucl. Chem. 1965, 27, 2573-2580. [CrossRef]

34. Sheldrick, G.M. Crystal structure refinement with SHELXL. Acta Crystallogr. Sect. C Struct. Chem. 2015, 71, 3-8. [CrossRef]

35. Bondi, A. van der Waals volumes and radii of metals in covalent compounds. J. Phys. Chem. 1966, 70, 3006-3007. [CrossRef]

36. Mantina, M.; Chamberlin, A.C.; Valero, R.; Cramer, C.J.; Truhlar, D.G. Consistent van der Waals Radii for the Whole Main Group. J. Phys. Chem. A 2009, 113, 5806-5812. [CrossRef]

37. Zelenkov, L.E.; Ivanov, D.M.; Avdontceva, M.S.; Novikov, A.S.; Bokach, N.A. Tetrachloromethane as halogen bond donor toward metal-bound halides. Z. Krist. Cryst. Mater. 2019, 234, 9-17. [CrossRef]

38. Dabranskaya, U.; Ivanov, D.M.; Novikov, A.S.; Matveychuk, Y.V.; Bokach, N.A.; Kukushkin, V.Y.

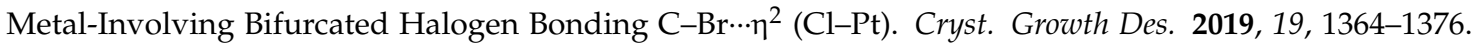
[CrossRef]

39. Burianova, V.K.; Bolotin, D.S.; Mikherdov, A.S.; Novikov, A.S.; Mokolokolo, P.P.; Roodt, A.; Boyarskiy, V.P.; Dar'in, D.; Krasavin, M.; Suslonov, V.V.; et al. Mechanism of generation of closo-decaborato amidrazones. Intramolecular non-covalent $\mathrm{B}-\mathrm{H} \cdots \pi(\mathrm{Ph})$ interaction determines stabilization of the configuration around the amidrazone $\mathrm{C}=\mathrm{N}$ bond. New J. Chem. 2018, 42, 8693-8703. [CrossRef]

40. Baykov, S.V.; Dabranskaya, U.; Ivanov, D.M.; Novikov, A.S.; Boyarskiy, V.P. Pt/Pd and I/Br isostructural exchange provides formation of $\mathrm{C}-\mathrm{I} \cdots \mathrm{Pd}, \mathrm{C}-\mathrm{Br} \cdots \mathrm{Pt}$, and $\mathrm{C}-\mathrm{Br} \cdots \mathrm{Pd}$ metal-involving halogen bonding. Cryst. Growth Des. 2018, 18, 5973-5980. [CrossRef] 
41. Bader, R.F.W. A quantum theory of molecular structure and its applications. Chem. Rev. 1991, 91, 893-928. [CrossRef]

42. Espinosa, E.; Alkorta, I.; Elguero, J.; Molins, E. From weak to strong interactions: A comprehensive analysis of the topological and energetic properties of the electron density distribution involving $\mathrm{X}-\mathrm{H} \cdots \mathrm{F}-\mathrm{Y}$ systems. J. Chem. Phys. 2002, 117, 5529-5542. [CrossRef]

43. Espinosa, E.; Molins, E.; Lecomte, C. Hydrogen bond strengths revealed by topological analyses of experimentally observed electron densities. Chem. Phys. Lett. 1998, 285, 170-173. [CrossRef]

44. Vener, M.V.; Egorova, A.N.; Churakov, A.V.; Tsirelson, V.G. Intermolecular hydrogen bond energies in crystals evaluated using electron density properties: DFT computations with periodic boundary conditions. J. Comput. Chem. 2012, 33, 2303-2309. [CrossRef] [PubMed]

45. Bartashevich, E.V.; Tsirelson, V.G. Interplay between non-covalent interactions in complexes and crystals with halogen bonds. Russ. Chem. Rev. 2014, 83, 1181-1203. [CrossRef]

46. Puttreddy, R.; von Essen, C.; Peuronen, A.; Lahtinen, M.; Rissanen, K. Halogen bonds in 2,5-dihalopyridinecopper(ii) chloride complexes. CrystEngComm 2018, 20, 1954-1959. [CrossRef]

(C) 2020 by the authors. Licensee MDPI, Basel, Switzerland. This article is an open access article distributed under the terms and conditions of the Creative Commons Attribution (CC BY) license (http://creativecommons.org/licenses/by/4.0/). 